\title{
USE OF MULBERRY POMACE AS SUBSTRATE FOR CITRIC ACID PRODUCTION BY Aspergillus niger MT-4
}

\author{
Rufina AIDYNOVA ${ }^{1}$, Nazli Pinar ARSLAN ${ }^{2}$, Mehmet Nuri AYDOĞAN ${ }^{1 *}$ \\ ${ }^{1}$ Department of Biology, Science Faculty, Atatürk University, 25240 Erzurum, TURKEY \\ ${ }^{2}$ Vocational School of Health Services, Bingöl University, Bingöl, TURKEY
}

Cite this article as:

Aidynova R., Arslan N.P., Aydoğan M.N. 2020. Use of Mulberry Pomace as Substrate for Citric Acid Production by Aspergillus niger Mt-4. Trakya Univ J Nat Sci, 21(2): 159-165, DOI: 10.23902/trkjnat.670859

Edited by:

Mustafa Yamaç

*Corresponding Author

Mehmet Nuri Aydoğan

mnaydogan@atauni.edu.tr

\section{ORCID ID:}

orcid.org/0000-0001-7518-4746

Key words:

Mulberry pomace

Waste material

Microbial production

Optimization

Citric acid

\begin{abstract}
Mulberry pomace (MP) is a waste material obtained after the production of pekmez, a traditional Turkish food. This study was performed to test the usability of MP as substrate for citric acid (CA) production by Aspergillus niger MT-4 for the first time. In the study, some culture conditions were also optimized to increase CA production in MP-based medium. Moisture, total carbohydrate, water-soluble carbohydrate, protein, lipid and ash contents of MP were determined as $31.1,47.1,1.3,13.4,1.8$ and $1.4 \%$, respectively. Experiments were carried out in $250 \mathrm{~mL}$ flasks containing $100 \mathrm{~mL}$ of production medium. Optimal MP concentration for both fungal biomass (FB) and CA production was determined as $120 \mathrm{~g} / \mathrm{L}$. All concentrations of $\mathrm{KH}_{2} \mathrm{PO}_{4}$ added to MP-based medium were found to decrease $\mathrm{CA}$ production but increase $\mathrm{FB}$ production. Optimal concentrations of $\mathrm{MgSO}_{4}$ and $\left(\mathrm{NH}_{4}\right)_{2} \mathrm{SO}_{4}$ for CA production were found as 1 and $2 \mathrm{~g} / \mathrm{L}$, respectively. The other optimal parameters were determined as an initial $\mathrm{pH}$ of 7.0 and an incubation period of 5 days. Under the optimized culture conditions, the amount of CA produced was determined as $24.6 \mathrm{~g} / \mathrm{L}$. On day 5, Yp/s, Yp/x and Yx/s were calculated as $0.2 \mathrm{~g} \mathrm{CA} / \mathrm{g}$ MP, $1.43 \mathrm{~g} \mathrm{CA} / \mathrm{g}$ FB and $0.14 \mathrm{~g} \mathrm{FB} / \mathrm{g}$ $\mathrm{MP}$, respectively.
\end{abstract}

Özet: Dut posası (DP), geleneksel bir Türk yiyeceği olan pekmez'in üretiminden sonra ortaya çıkan bir atık maddedir. Bu çalışma, Aspergillus niger MT-4 ile sitrik asit (SA) üretimi için DP'nin substrat olarak kullanılabilirliğini test etmek için gerçekleştirilmiştir. Çalışmada ayrıca, SA üretimini artırmak için bazı kültür koşulları da optimize edilmiştir. MP'nin nem, toplam karbonhidrat, suda-çözünür karbonhidrat, protein, lipid ve kül içerikleri sırasıyla $\% 31,1 ; 47,1 ; 1,3$; 13,$4 ; 1,8$ ve 1,4 olarak belirlenmiştir. Deneyler, üretim besiyerinin $100 \mathrm{ml}$ 'sini içeren $250 \mathrm{ml}$ 'lik erlenler içerisinde gerçekleştirilmiştir. Hem fungal biyokütle (FB) hem de SA üretimi için optimum DP konsantrasyonu, $120 \mathrm{gr} / \mathrm{lt}$ olarak belirlenmiştir. DP bazlı ortama eklenen tüm $\mathrm{KH}_{2} \mathrm{PO}_{4}$ konsantrasyonlarının SA üretimini azalttığı fakat FB üretimini artırdığı belirlenmiştir. SA üretimi için $\mathrm{MgSO}_{4}$ ve $\left(\mathrm{NH}_{4}\right)_{2} \mathrm{SO}_{4}$ 'ün optimal konsantrasyonları sırasıyla 1 ve $2 \mathrm{gr} / \mathrm{lt}$ olarak bulunmuştur. Diğer optimal parametreler, başlangıç pH'sı 7,0 ve inkübasyon süresi 5 gün olarak belirlenmiştir. Optimize edilmiş kültür koşulları altında, üretilen SA miktarı 24,6 gr/lt olarak belirlenmiştir. Beşinci günde, $\mathrm{Yp} / \mathrm{s}$; Yp/x ve $\mathrm{Yx} / \mathrm{s}$ sirasıyla $0,2 \mathrm{gr} \mathrm{SA} / \mathrm{gr}$ DP; $1,43 \mathrm{gr} \mathrm{SA} / \mathrm{gr}$ FB ve $0,14 \mathrm{gr} \mathrm{FB/gr}$ DP olarak hesaplanmıştır. DP'nin SA dahil mikrobiyal metabolitlerin üretimi için fermentasyon substratı olarak kullanılabilirliği ilk kez bu çalıșmada test edilmiştir.

\section{Introduction}

Mulberry belongs to the Morus L. genus of the Moraceae family. The genus includes 24 species and one subspecies. $M$. alba L., $M$. nigra L. and $M$. rubra L. are the main species grown in Turkey. Mulberry cultivation in Turkey has long been known dating back to 400 years ago (Ercisli \& Orhan 2007).

Mulberry fruits in Turkey are consumed as fresh or fresh fruits are processed to prepare traditional products such as pekmez, pestil and köme. Pekmez, which is consumed mainly in breakfast is made from different fruits but grape and mulberry are the most common fruits used in the process (Gunes \& Cekic 2004, Cakmakci \& Tosun 2010). For pekmez production, mulberry fruits are boiled in water until the sugars and other organic substances are passed into the water. After the boiling process, the mixture is filtered and the liquid fraction obtained is used for pekmez production. The remaining non-degrading solid fraction is referred to as pomace. Mulbery pomace (MP) is used as animal feed additives and no other use in Turkey is known. MP has also no important use in any application in the world. 
Citric acid (CA) is an organic acid commonly used in the food, pharmaceutical, cosmetic, detergent, chemical and textile industries (Dhillon et al. 2011, Torrado et al. 2011). Most of CA is used in food (about 70\%) and pharmaceutical (12\%) industries (Darouneh et al. 2009). The production of CA is carried out by extraction from plants or by chemical synthesis and microbial fermentation but about $99 \%$ of the production is achieved via microbial fermentation (Taskin et al. 2013, Arslan et al. 2016). Several microorganisms such as bacteria, filamentous fungi and yeasts are capable of producing CA. For example, filamentous fungi such as Aspergillus niger van Tieghem, A. wenti Wehmer, A. foetidus Thom \& Raper and $A$. carbonaries (Bainier) Thom and Trichoderma viride Pers. and Mucor pyriformis Scop. have been reported to be good producers of CA. Similarly, yeast species belonging to different genera such as Candida Berkhout, Yarrowia Van der Walt \& Arx, Pichia E.C. Hansen, Hansenula Syd. \& P. Syd. have been documented to be potential producers of CA (Soccol et al. 2006, Show et al. 2015). Despite the variety of these different producers, microbial production of CA is mainly performed using A. niger since this filamentous fungus is able to use numerous cheap raw materials and to accumulate CA with higher yields (Soccol et al. 2006, Angumeenal \& Venkappayya 2013, Taskin et al. 2013, Arslan et al. 2016). Microbial CA production is achieved by three different fermentation techniques as surface fermentation, submerged fermentation and solid-state fermentation. Submerged fermentation is performed using shaking flasks or fermenters. Shaking flask technique is usually used for the optimization of fermentation conditions (Show et al. 2015). CA production is affected by operational culture conditions such as $\mathrm{pH}$, temperature, oxygen, incubation time, substrate concentration, minerals, carbon and nitrogen sources. In particular, high carbon source concentrations under the nitrogen and phosphorus-limited conditions are known to significantly increase CA synthesis (Soccol et al. 2006, Darouneh et al. 2009, Show et al. 2015, Arslan et al. 2016). Therefore, optimization of culture conditions in CA production is considered an important criterion.

Growth substrates make up the major part of the production costs in fermentation studies. Therefore, selection of a low-cost substrate is considered as a major aspect in microbial fermentation studies (Taskin et al. 2013). For example, with the aim of reducing the production cost in the production of $\mathrm{CA}$, cheap agricultural wastes and/or byproducts such as beet molasses, black strap molasses, cane molasses, $n$-paraffin, glycerol, whey and waste oil are usually preferred as substrate (Soccol et al. 2006, Torrado et al. 2011; Show et al. 2015, Arslan et al. 2016). However, to our best knowledge, there is no study on the use of MP as a substrate in microbial fermentations. Therefore, the present study was performed to produce CA from A. niger MT-4 in shaking flask culture using MP as substrate and to optimize some culture conditions for enhancement of CA production.

\section{Materials and Methods}

\section{Microorganism, materials and chemicals}

Aspergillus niger MT-4 was obtained from Professor Mesut Taskin from the Department of Molecular Biology and Genetics, Atatürk University, Turkey (Taskin et al. (2013). MP was obtained from a commercial company producing mulberry pekmez in Erzurum province (Turkey). Potato dextrose agar (PDA) and potato dextrose broth (PDB) were purchased from Merck (Germany). The other chemicals (Tween 80, phenol, sulfuric acid, acetylacetone, Ehrlich reagent, $\mathrm{N}$-acetylglucosamine, citric acid, pyridine and acetic anhydride) were purchased from Sigma (USA).

\section{Preparation of spore suspension}

The fungal culture was left to sporulation at $30^{\circ} \mathrm{C}$ for 10 days on the slant containing PDA medium. At the end of this period, conidia were suspended in sterile physiological water including a surfactant $(0.2 \mathrm{~mL} / \mathrm{L}$ Tween 80 ). The slant was vortexed for approximately 5 min to distribute the spores homogeneously. The prepared suspension was then filtrated through three layers of muslin to eliminate hyphae and unsuspended conidia. The spore concentrations were determined by using a haemocytometer and the final spore count was adjusted to $10^{6}$ spores per $\mathrm{mL}$. During the experiments, $1 \mathrm{~mL}$ of the prepared spore suspension was used for inoculation of the production medium containing MP.

\section{Determination of chemical composition of $M P$}

The moisture content of MP was determined by the weight difference before and after drying in a oven for about $24 \mathrm{~h}$ at $100^{\circ} \mathrm{C}$, up to constant weight. Total nitrogen content was determined using a micro-Kjeldahl apparatus, and the protein content was estimated by multiplying the nitrogen content by 6.25 . Ash content was determined by combusting MP for $3 \mathrm{~h}$ in a muffle furnace (Thermolyne 62 700, Barnstead/Thermolyne Corp., Dubuque, IA, USA) at $550^{\circ} \mathrm{C}$. The total lipid content was determined according to the Soxhlet extraction method using diethyl ether as solvent. Water-soluble carbohydrate and total carbohydrate contents were determined using phenolsulfuric acid method (Dubois et al. 1956). For analysis of water-soluble carbohydrates, MP was boiled in water for about $5 \mathrm{~min}$. The suspension was then centrifuged to remove solid particles. Finally, the analysis of watersoluble carbohydrates in the obtained liquid fraction (supernatant) was performed by the phenol-sulfuric acid method.

\section{CA production in mulberry pomace-based medium}

CA production using A. niger MT-4 was performed in $250 \mathrm{~mL}$ flasks containing $100 \mathrm{~mL}$ of sterile production medium. The production medium ( $\mathrm{pH}$ 6.0) was prepared by adding MP into distilled water. Optimization of fermentation parameters was performed by using onefactor-at-a-time method. Initial experiments were performed to determine the most favorable concentration of dried MP. For this purpose, different concentrations of 
dried MP from 30 to $150 \mathrm{~g} / \mathrm{L}$ were tested. The effects of different concentrations of $\mathrm{KH}_{2} \mathrm{PO}_{4}(0-1.5 \mathrm{~g} / \mathrm{L}), \mathrm{MgSO}_{4}$ $(0-2.0 \mathrm{~g} / \mathrm{L})$ and $\left(\mathrm{NH}_{4}\right)_{2} \mathrm{SO}_{4}(0-4 \mathrm{~g} / \mathrm{L})$ on CA production in MP-based medium were tested. Then, different initial $\mathrm{pHs}$ ( $\mathrm{pH} 2-8$ ) and incubation times (2-7 days) were tested to increase CA production in MP-based medium. All the experiments were performed at $30^{\circ} \mathrm{C}$ on a shaking incubator at $150 \mathrm{rpm}$.

\section{Analytical methods}

Final $\mathrm{pH}$ of the culture and the initial $\mathrm{pH}$ of the MPbased medium were measured using a $\mathrm{pH}$ meter (Ohaus Starter 3100). $10 \mathrm{~mL}$ sample taken from the culture after an appropriate cultivation was centrifuged at $5000 \mathrm{rpm}$ for 5 min. The obtained supernatant was used for CA analysis. The concentration of $\mathrm{CA}$ was determined according to the acetic anhydride method (Marier \& Boulet 1958). In brief, $1 \mathrm{~mL}$ of supernatant was first mixed with $1.3 \mathrm{~mL}$ of pyridine. Then, $5.7 \mathrm{~mL}$ acetic anhydride was added into the samples. After incubation at $32^{\circ} \mathrm{C}$ for $30 \mathrm{~min}$, absorbance of $\mathrm{CA}$ was determined spectrophotometrically at $410 \mathrm{~nm}$. Anhydrous CA (50$300 \mu \mathrm{g} / \mathrm{mL}$ ) was used as standard. In case of very intense color formation, samples were diluted with distilled water. CA content of the samples was determined according to the standard graph prepared with anhydrous CA.

During the incubation period, some of the MP was not used as a substrate by the fungus. This part, which was not used as a substrate and remained in the culture, was named non-fermented MP. At the end of the cultivation period, it was observed that the nonfermented MP was attached to the fungal biomass (FB) and not separated from it by centrifugation. Therefore, the solid fraction (non-fermented MP + FB) consisting of non-fermented MP and FB was named as total biomass (TP).

For the determination of FB amount in TP, Nacetylglucosamine content in TP was measured. In brief, $1 \mathrm{~mL}$ of concentrated $\mathrm{H}_{2} \mathrm{SO}_{4}$ was added to $0.5 \mathrm{~g}$ of TP. Following this, acetylacetone reagent $(1 \mathrm{~mL})$ was added to the mixture. The mixture was incubated in a boiling water bath for $20 \mathrm{~min}$ and then cooled at room temperature. Then, $6 \mathrm{~mL}$ of ethanol and $1 \mathrm{~mL}$ of Ehrlich reagent were added to the cooled mixture. The final mixture was again left to incubation at $65^{\circ} \mathrm{C}$ for $10 \mathrm{~min}$ and then cooled at the room temperature. Finally, optical density (OD) of the final mixture was determined at $530 \mathrm{~nm}$ (Velmurugan et al. 2011). The obtained absorbance was then used for the calculation of FB produced in MP-based medium. For this purpose, the following simple equation was used.

$$
\mathrm{FB}=(\mathrm{A} 1 / \mathrm{A} 2) \times \mathrm{TB}
$$

A1: The absorbance assayed for $\mathrm{N}$-acetylglucosamine content in per $\mathrm{g}$ of the dried TB (TB; FB + non-fermented $\mathrm{MP}$ ) in MP-based medium at the end of cultivation period.
A2: The absorbance assayed for $\mathrm{N}$-acetylglucosamine content in per $\mathrm{g}$ of dried FB, which was produced in standard PDB medium at the end of cultivation period.

TB: Total biomass (FB + non-fermented MP) in MPbased medium at the end of cultivation period.

\section{$\underline{\text { Statistical analysis }}$}

Each analysis was repeated at least three times in two replicates. Statistical difference was analyzed with oneway ANOVA in the SPSS 15.0 package program at $\mathrm{P}$ $<0.05$ significance level.

\section{Results}

\section{Chemical composition of $M P$}

The moisture content of raw MP was determined as $31.1 \%$. Total carbohydrate, protein, lipid and ash contents of MP were determined as 47.1, 13.4, 1.8 and 1.4\%, respectively. The ratio of water-soluble carbohydrates was found to be $1.3 \%$.

Table 1. Chemical composition of MP.

\begin{tabular}{lc}
\hline \multicolumn{1}{c}{ Components } & Content (\%) \\
\hline \hline Moisture & $31.1 \pm 1.90$ \\
Protein & $13.4 \pm 1.04$ \\
Lipids & $1.8 \pm 0.17$ \\
Ash & $1.4 \pm 0.12$ \\
Total carbohydrate & $47.1 \pm 2.72$ \\
Water-soluble carbohydrate & $1.3 \pm 0.10$ \\
\hline \hline
\end{tabular}

All measurements are mean \pm standard deviations $( \pm \mathrm{SD})$ of six determinations $(n=6)$.

Optimization of CA production from A. niger in MP. based medium

In the first step of the study, different concentrations of dried MP were tested for production of CA and FB from A. niger MT-4. Increased MP concentration increased both $\mathrm{CA}$ synthesis and fungal growth, and maximum concentrations of CA (10.6 g/L) and FB (14.3 $\mathrm{g} / \mathrm{L})$ were reached in medium containing $120 \mathrm{~g} / \mathrm{L} \mathrm{MP}$ (Fig. 1). Based on these results, the following experiments were performed on medium containing $120 \mathrm{~g} / \mathrm{L} \mathrm{MP}$.

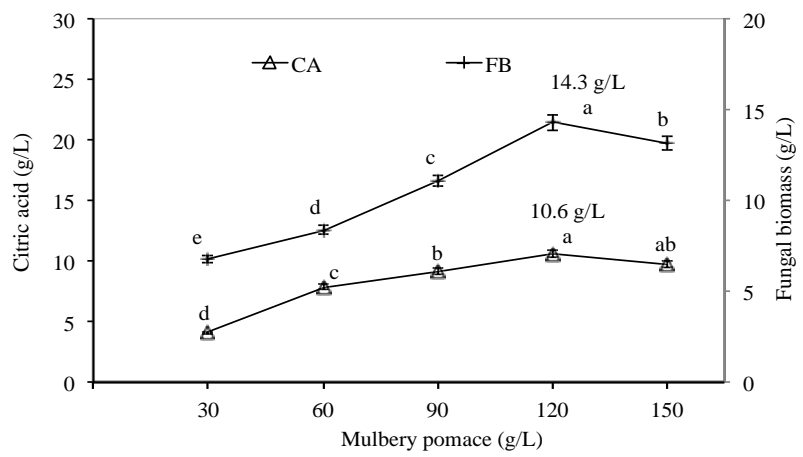

Fig. 1. Effect of MP on CA synthesis and fungal growth in $A$. niger MT-4. Culture conditions: initial $\mathrm{pH}$ 6.0, temperature $30^{\circ} \mathrm{C}$, shaking speed $150 \mathrm{rpm}$ and incubation time 4 days. All the measurements were mean \pm standard deviations $( \pm \mathrm{SD})$ of six determinations $(n=6)$. Different letters in the line of CA and FB indicate significant differences $(\mathrm{P}<0.05)$. 

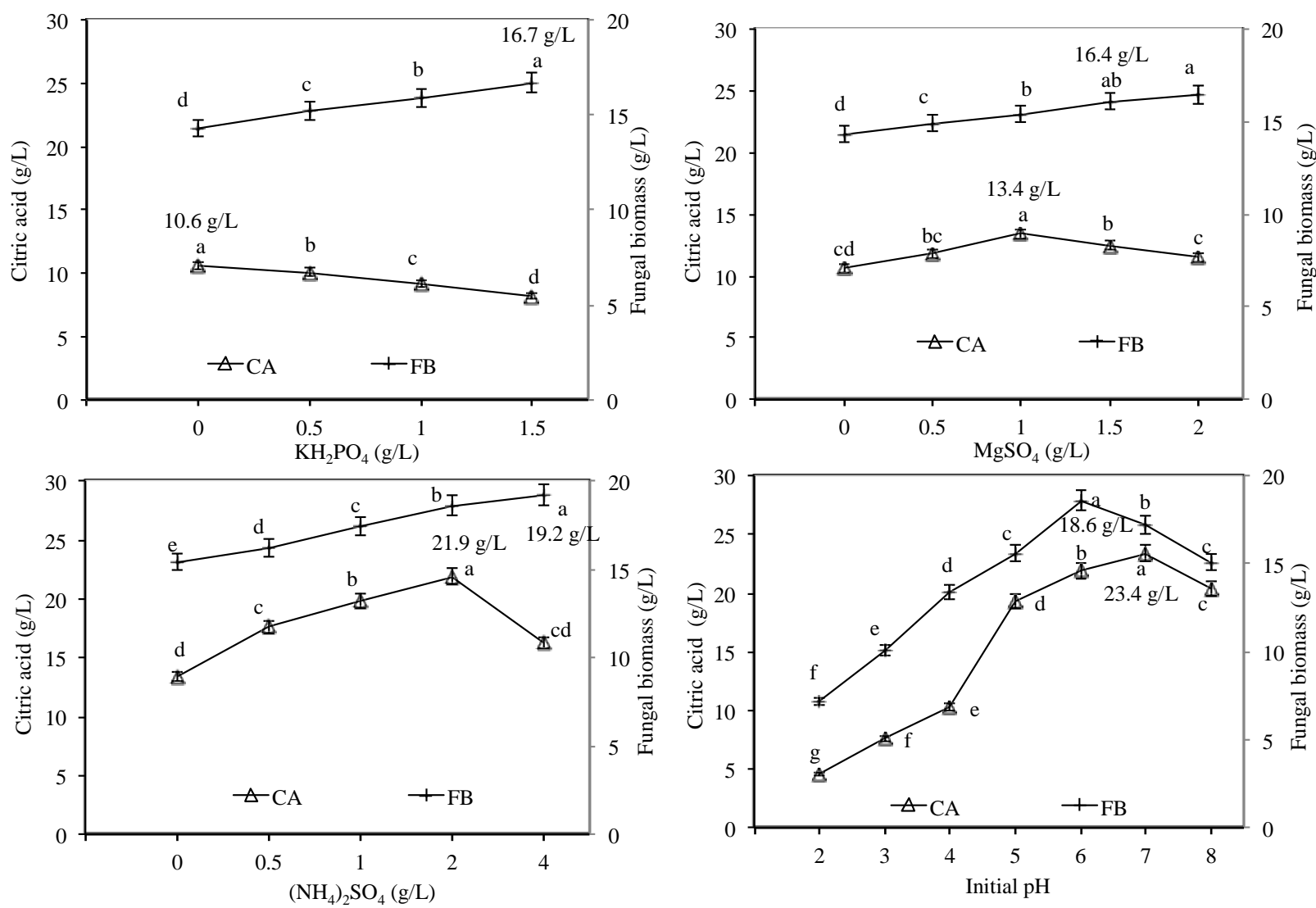

Fig. 2. Effect of $\mathrm{KH}_{2} \mathrm{PO}_{4}, \mathrm{MgSO}_{4},\left(\mathrm{NH}_{4}\right)_{2} \mathrm{SO}_{4}$ and initial $\mathrm{pH}$ on citric acid synthesis and fungal growth in A. niger MT-4. Culture conditions for optimization of $\mathrm{KH}_{2} \mathrm{PO}_{4}$ concentration: $\mathrm{MP}$ concentration $120 \mathrm{~g} / \mathrm{L}$ and initial $\mathrm{pH}$ 6.0. Culture conditions for optimization $\mathrm{MgSO}_{4}$ concentration: MP concentration $120 \mathrm{~g} / \mathrm{L}, \mathrm{KH}_{2} \mathrm{PO}_{4} 0 \mathrm{~g} / \mathrm{L}$ and initial pH 6.0. Culture conditions for optimization of $\left(\mathrm{NH}_{4}\right)_{2} \mathrm{SO}_{4}$ concentration: MP concentration $120 \mathrm{~g} / \mathrm{L}, \mathrm{KH}_{2} \mathrm{PO}_{4} 0 \mathrm{~g} / \mathrm{L}, \mathrm{MgSO}_{4} 1 \mathrm{~g} / \mathrm{L}$ and initial pH 6.0. Culture conditions for optimization of initial pH: MP concentration $120 \mathrm{~g} / \mathrm{L}, \mathrm{KH}_{2} \mathrm{PO}_{4} 0 \mathrm{~g} / \mathrm{L}, \mathrm{MgSO}_{4} 1 \mathrm{~g} / \mathrm{L}$ and $\left(\mathrm{NH}_{4}\right)_{2} \mathrm{SO}_{4} 2 \mathrm{~g} / \mathrm{L}$. All experiments were performed at $30^{\circ} \mathrm{C}$ and 150 rpm for 4 days. All the measurements are mean \pm standard deviations $( \pm \mathrm{SD})$ of six determinations $(\mathrm{n}=6)$. Different letters in the line of $\mathrm{CA}$ and $\mathrm{FB}$ indicate significant differences $(\mathrm{P}<0.05)$.

After determination of the optimum concentration of $\mathrm{MP}$, the effect of different concentrations of $\mathrm{KH}_{2} \mathrm{PO}_{4}$ on cell growth and $\mathrm{CA}$ synthesis was investigated. The maximum $\mathrm{CA}$ production was achieved in the control medium $\left(\mathrm{KH}_{2} \mathrm{PO}_{4}\right.$-free medium), whereas $\mathrm{FB}$ reached to the maximum $(16.7 \mathrm{~g} / \mathrm{L})$ when $1.5 \mathrm{~g} / \mathrm{L} \mathrm{KH}_{2} \mathrm{PO}_{4}$ was added to MP-based medium (Fig. 2). Considering these results, the following experiments were carried out in the medium, which was not supplemented with $\mathrm{KH}_{2} \mathrm{PO}_{4}$. All tested concentrations of $\mathrm{MgSO}_{4}$ increased fungal growth (Fig. 2). In contrast to fungal growth, the maximum CA production $(13.4 \mathrm{~g} / \mathrm{L})$ was achieved in the medium supplemented with $1 \mathrm{~g} / \mathrm{L} \mathrm{MgSO}_{4}$. However, excessive concentrations of $\mathrm{MgSO}_{4}$ gradually decreased $\mathrm{CA}$ production. For example, CA production decreased up to $11.5 \mathrm{~g} / \mathrm{L}$ when $2 \mathrm{~g} / \mathrm{L} \mathrm{MgSO}_{4}$ was added to the medium. Therefore, the subsequent experiments were performed in the medium supplemented with $1 \mathrm{~g} / \mathrm{L} \mathrm{MgSO} 4$. The experiments revealed that $2 \mathrm{~g} / \mathrm{L} \quad\left(\mathrm{NH}_{4}\right)_{2} \mathrm{SO}_{4}$ caused maximum CA production $(21.9 \mathrm{~g} / \mathrm{L})$ but higher $\left(\mathrm{NH}_{4}\right)_{2} \mathrm{SO}_{4}$ concentrations decreased CA production. In contrast to $\mathrm{CA}$ synthesis, all tested concentrations of $\left(\mathrm{NH}_{4}\right)_{2} \mathrm{SO}_{4}$ increased fungal growth and the maximum $\mathrm{FB}$ $(19.2 \mathrm{~g} / \mathrm{L})$ was reached at the highest $\left(\mathrm{NH}_{4}\right)_{2} \mathrm{SO}_{4}$ of $4 \mathrm{~g} / \mathrm{L}$
(Fig. 2). Taking into account these results, an ammonium sulfate concentration of $2 \mathrm{~g} / \mathrm{L}$ resulting in the maximum CA production was chosen for subsequent experiments.

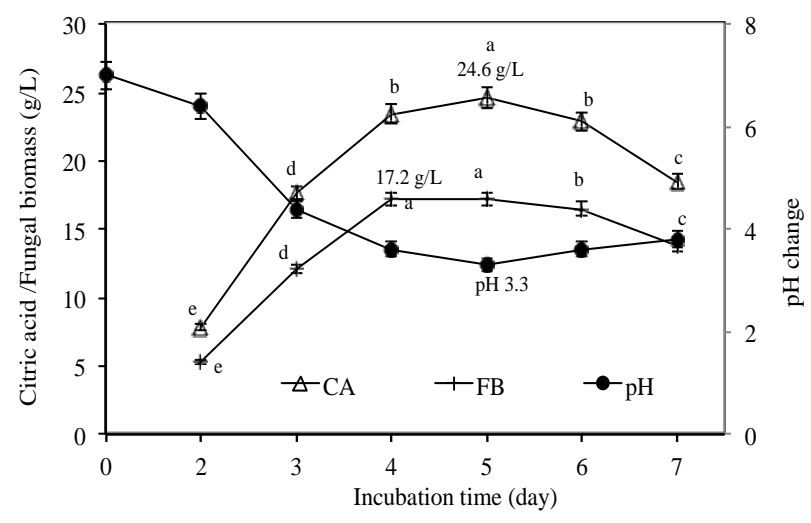

Fig. 3. Effect of incubation time on cell growth, CA synthesis and $\mathrm{pH}$ change in MP-based medium. Culture conditions: MP concentration $120 \mathrm{~g} / \mathrm{L}, \mathrm{KH}_{2} \mathrm{PO}_{4} 0 \mathrm{~g} / \mathrm{L}, \mathrm{MgSO}_{4} 1 \mathrm{~g} / \mathrm{L},\left(\mathrm{NH}_{4}\right)_{2} \mathrm{SO}_{4}$ $2 \mathrm{~g} / \mathrm{L}$, initial $\mathrm{pH} 7.0$, temperature $30^{\circ} \mathrm{C}$, shaking speed $150 \mathrm{rpm}$. All the measurements are mean \pm standard deviations $( \pm \mathrm{SD})$ of six determinations $(n=6)$. Different letters in the line of CA and $\mathrm{FB}$ indicate significant differences $(\mathrm{P}<0.05)$. 
When the effect of initial $\mathrm{pH}$ on $\mathrm{CA}$ synthesis and fungal growth was investigated, it was determined that maximum CA synthesis $(23.4 \mathrm{~g} / \mathrm{L})$ occurred at an initial $\mathrm{pH}$ of 7.0 , but FB reached to the maximum $(18.6 \mathrm{~g} / \mathrm{L})$ at pH 6.0 (Fig. 2). Based on this result, the following experiments were carried out in the medium with an initial $\mathrm{pH}$ of 7.0 .

The highest increase in CA production occurred in the first 4 days of incubation and CA concentration reached to the maximum $(24.6 \mathrm{~g} / \mathrm{L}$ ) on day 5 (Fig. 3). FB reached the highest value $(17.2 \mathrm{~g} / \mathrm{L})$ on day 4 and remained stable on day 5. But, reductions in both FB and CA concentrations were observed after the $5^{\text {th }}$ day. For example, at the end of day $7, \mathrm{FB}$ and $\mathrm{CA}$ concentrations were measured as 13.8 and $18.5 \mathrm{~g} / \mathrm{L}$, respectively. Since maximum productions of $\mathrm{CA}(24.6 \mathrm{~g} / \mathrm{L})$ and $\mathrm{FB}(17.2$ $\mathrm{g} / \mathrm{L})$ were achieved at $120 \mathrm{~g} / \mathrm{L} \mathrm{MP}$ concentration, Yp/s (gram CA produced/gram substrate), Yp/x (gram CA produced/ gram $\mathrm{FB}$ produced) and $\mathrm{Yx} / \mathrm{s}$ (gram $\mathrm{FB}$ produced/gram substrate) were calculated as $0.2 \mathrm{~g} \mathrm{CA} / \mathrm{g}$ MP, $1.43 \mathrm{~g} \mathrm{CA} / \mathrm{g} \mathrm{FB}$ and $0.14 \mathrm{~g} \mathrm{FB} / \mathrm{g} \mathrm{MP}$, respectively. When initial $\mathrm{pH}$ was adjusted at 7.0 , there was a continuous decrease in culture $\mathrm{pH}$ up to the end of $5^{\text {th }}$ day, but an increase in culture $\mathrm{pH}$ was observed again after $5^{\text {th }}$ day. Lowest $\mathrm{pH}$ value ( $\mathrm{pH}$ 3.3) was detected on day 5, by which the maximum $\mathrm{CA}$ concentration was reached.

\section{Discussion}

The previous studies demonstrated that hydrolysates, which are prepared from agricultural wastes and/or byproducts using chemical or enzymatic hydrolysis processes can be utilized as substrates for CA production in the culture of A. niger strains (Watanabe et al. 1998, Hu et al. 2014, Faruk et al. 2014, Muna et al. 2018). But, it is well known that when chemicals and/or enzymes are used for the preparation of hydrolysates, the production cost of CA increases. Therefore, researchers suggested using Aspergillus strains in CA production, which are capable of secreting hydrolytic enzymes (amylase, cellulose, pectinase etc.) and thereby growing directly on agricultural wastes and/or by-products (Andersen et al. 2011, Afify et al. 2012, Rehman et al. 2014). However, the potential of $A$. niger to produce CA on MP, which is not subjected to a pretreatment process such as chemical or enzymatic hydrolysis, has not been studied yet.

The chemical analyses revealed that dried MP contained vey low amount of water-soluble carbohydrates. This situation can be attributed to the boiling of mulberry fruits at high temperature for a long time during the production of pekmez (molasses). In other words, since water-soluble carbohydrates such as sucrose and glucose in mulberry fruits passed into pekmez, there was rather low soluble carbohydrate in MP. On the contrary, the experiments showed that the total carbohydrate content of MP was high. These carbohydrates may include pectin, starch, cellulose and soluble sugars. Considering that A. niger strains have hydrolytic enzymes, it is possible that insoluble carbohydrates such as pectin, starch and cellulose in MP can be used as carbon source by A. niger MT-4. Besides, it was determined in this study that MP was rich in ash. Considering the knowledge that ash consists of macro and micro-elements, it is possible to say that MP can also be used as a mineral source by this filamentous fungus. The experiments also indicated that MP contained protein and therefore it may be used as a nitrogen source in the medium.

Usability of non-pretreated MP as a substrate for CA production from A. niger MT-4 was tested in this study. In the first stage, MP was used as a sole source of all nutritional factors (minerals, carbon and nitrogen source) for production of FB and CA. The maximum CA and FB production were achieved in medium containing $120 \mathrm{~g} / \mathrm{L}$ MP, while higher MP concentrations decreased both CA and FB production. This result might be attributed to the increase in solid/liquid ratio of the production medium. Namely, high solid ratio (high MP concentration) might have prevented the homogeneous mixing of the substrate and sufficient oxygen intake into the culture. Since oxygen is particularly important for CA synthesis (Max et al. 2010), the decrease in oxygen concentration might have limited CA synthesis in MP-based medium.

The experiments revealed that when $\mathrm{KH}_{2} \mathrm{PO}_{4}$ was used as phosphorus $(\mathrm{P})$ and potassium $(\mathrm{K})$ source, all concentrations caused inhibition on $\mathrm{CA}$ synthesis but a continuous increase in fungal growth. These results should not be so surprising, because it has been reported that excessive $\mathrm{P}$ concentrations can limit CA synthesis but increase fungal growth in A. niger (Jernejc et al. 1982, Chen 1996, Vandenberghe et al. 1999, Max et al. 2010, Angumeenal \& Venkappayya 2013). These results indicate that $\mathrm{P}$ content of MP was sufficient to promote $\mathrm{CA}$ synthesis and no additional $\mathrm{P}$ source is required in MP-based medium for CA synthesis. When $\mathrm{MgSO}_{4}$ was added into the medium, its concentrations $\leq 1 \mathrm{~g} / \mathrm{L}$ promoted CA synthesis but higher concentrations caused a slight inhibition. This finding is good agreement with the fact that although $\mathrm{MgSO}_{4}$ has a beneficial effect on CA synthesis in A. niger, its excessive concentrations can inhibit CA synthesis (Vandenberghe et al. 1999, Ikram-ul et al. 2004).

It has been documented that $\mathrm{CA}$ production is directly influenced by the nitrogen source, and $\left(\mathrm{NH}_{4}\right)_{2} \mathrm{SO}_{4}$ is a good nitrogen source for CA production (Vandenberghe et al. 1999, Max et al. 2010). Considering this knowledge, the present experiments also focused on investigating the effect of $\left(\mathrm{NH}_{4}\right)_{2} \mathrm{SO}_{4}$ as additional nitrogen source on CA production in MP-based medium. The experiments showed that $\mathrm{CA}$ production could be achieved in MPbased medium without $\left(\mathrm{NH}_{4}\right)_{2} \mathrm{SO}_{4}$ (additional nitrogen source). This can be explained by the use of proteinous compounds in MP as nitrogen source in the medium. However, it was seen that $\left(\mathrm{NH}_{4}\right)_{2} \mathrm{SO}_{4}$ concentrations $\leq 2$ $\mathrm{g} / \mathrm{L}$ caused increases in CA synthesis. This result revealed that the nitrogen in MP was insufficient for the production of high amounts of CA and additional nitrogen was required in the medium. The results also showed that 
$\left(\mathrm{NH}_{4}\right)_{2} \mathrm{SO}_{4}$ concentrations over $2 \mathrm{~g} / \mathrm{L}$ decreased CA synthesis in the culture. Conversely, there was a continuous increase in $\mathrm{FB}$ even at the highest $\left(\mathrm{NH}_{4}\right)_{2} \mathrm{SO}_{4}$ of $4 \mathrm{~g} / \mathrm{L}$. This finding is in good agreement with the fact that excessive nitrogen concentration increases fungal growth but decreases the amount of CA produced (Hang et al. 1977, Vandenberghe et al. 1999, Soccol et al. 2006, Auta et al. 2014, Arslan et al. 2016).

The results showed that initial $\mathrm{pH}$ values between 5 and 7 were more suitable for $\mathrm{CA}$ and FB production. Especially, initial $\mathrm{pH}$ of 7.0 was the superior for $\mathrm{CA}$ production. It was reported that although acidic $\mathrm{pHs}$ such as $\mathrm{pH} 2$ and 3 are more suitable for CA synthesis in $A$. niger, the germination of $A$. niger spores requires $\mathrm{pH}>5$ (Soccol et al. 2006). Namely, the initial $\mathrm{pH}$ of the culture for CA synthesis in A. niger should be adjusted to $\mathrm{pH}$ levels $>5$. Therefore, it should not be surprising that initial pHs of 5-7 lead to more CA synthesis in A. niger MT-4.

The final experiments showed that FB and CA reached to maximum concentrations on days 4 and 5, respectively. The maximum increases in concentrations of both CA and FB were achieved in the first four days of fermentation. These results are similar to those reported in previous studies (Kareem et al. 2010, Taskin et al. 2013, Dienye et al. 2018) showing that incubation time affects cell growth and CA synthesis in A. niger. On day 5, CA concentration and $\mathrm{CA}$ yield (Yp/s) were determined as $24.6 \mathrm{~g} / \mathrm{L}$ and 0.2 g CA/g MP, respectively. The CA yield achieved in submerged culture was similar to those reported in

\section{References}

1. Afify, M.M., Al Abboud, M.A. \& El-Ghany, T.A. 2012. Bioenhancement of citric acid production under optimized condition of cellulase and pectinase productivity from potato wastes. Journal of Jazan University-Applied Sciences Branch, 1(2): 60-72.

2. Alben, E. \& Erkmen, O. 2004. Production of citric acid from a new substrate, undersized semolina, by Aspergillus niger. Food Technology and Biotechnology, 42(1): 19-22.

3. Ali, S., Qadeer, M. A. \& Iqbal, J. 2002. Citric acid fermentation by mutant strain of Aspergillus niger GCMC7 using molasses based medium. Electronic Journal of Biotechnology, 5(2): 8-9.

4. Andersen, M.R., Salazar, M.P., Schaap, P.J., et al. 2011. Comparative genomics of citric-acid-producing Aspergillus niger ATCC 1015 versus enzyme-producing CBS 513.88. Genome Research, 21(6): 885-897.

5. Angumeenal, A.R. \& Venkappayya, D. 2013. An overview of citric acid production. LWT-Food Science and Technology, 50(2): 367-370.

6. Arslan, N.P., Aydogan, M.N. \& Taskin, M. 2016. Citric acid production from partly deproteinized whey under nonsterile culture conditions using immobilized cells of lactose-positive and cold-adapted Yarrowia lipolytica B9. Journal of Biotechnology, 231: 32-39.

7. Auta, H.S., Abidoye, K.T., Tahir, H., Ibrahim, A.D. \& Aransiola, S.A. 2014. Citric acid production by Aspergillus previous studies (Alben \& Erkmen 2004, Guc \& Erkmen 2017).

The reduction in fungal biomass after day 5 may be attributed to cell lysis due to the depletion of nutritional compounds. The most likely cause of the decrease in CA concentration after day 5 may be the degradation of CA by the enzymes released into the culture when the fungal cells are lysed. A continuous drop in culture $\mathrm{pH}$ up to the end of the $5^{\text {th }}$ day could be ascribed to the production of organic acids, especially CA. Similar decreases in culture $\mathrm{pH}$ during $\mathrm{CA}$ production were also reported in the previous studies (Ali et al. 2002, Dienye et al. 2018). Increment in culture $\mathrm{pH}$ after the $5^{\text {th }}$ day might be attributed to the releasing into the culture of some alkaline compounds due to fungal cell lysis.

In conclusion, this study revealed that MP alone could be used as a complex substrate for CA production with $A$. niger MT-4, but more CA production could be achieved when MP-based medium was supplemented with $\left(\mathrm{NH}_{4}\right)_{2} \mathrm{SO}_{4}$ and $\mathrm{MgSO}_{4}$ at suitable concentrations. On the other hand, optimization of initial $\mathrm{pH}$ and incubation time could increase CA production in MP-based medium. When the optimal culture parameters are selected, 24.6 $\mathrm{g} / \mathrm{L}$ CA could be produced in MP-based medium. The use of MP in CA production will contribute to the reduction of both fermentation cost and environmental pollution. In future studies, MP can be also tested as a substrate in the culture of microorganisms in the production of other substances such as lactic acid, acetic acid, single cell protein, ethanol, pigment and polysaccharide.

niger cultivated on Parkia biglobosa fruit pulp. International Scholarly Research Notices, 2014. http://dx.doi.org/10.1155/2014/762021

8. Cakmakci, S. \& Tosun, M. 2010. Characteristics of mulberry pekmez with cornelian cherry. International Journal of Food Properties, 13(4): 713-722.

9. Chen, H.C. 1996. Optimizing the concentrations of carbon, nitrogen and phosphorus in a citric acid fermentation with response surface method. Food Biotechnology, 10(1): 1327.

10. Darouneh, E., Alavi, A., Vosoughi, M., Arjm, M., Seifkordi, A. \& Rajabi, R. 2009. Citric acid production: Surface culture versus submerged culture. African Journal of Microbiology Research, 3(9): 541-545.

11. Dhillon, G.S., Brar, S.K., Verma, M., Tyagi, R.D., 2011. Recent advances in citric acid bio-production and recovery. Food and Bioprocess Technology, 4(4): 505-529.

12. Dienye, B.N., Ahaotu, I., Agwa, O.K. \& Odu, N.N. 2018. Citric acid production potential of Aspergillus niger using Chrysophyllum albidum peel. Advances in Bioscience and Biotechnology, 9(4): 190-203.

13. Ercisli, S. \& Orhan, E. 2007. Chemical composition of white (Morus alba), red (Morus rubra) and black (Morus nigra) mulberry fruits. Food Chemistry, 103(4): 1380-1384. 
14. Guc, S. \& Erkmen, O. 2017. Citric acid production from nontreated beet molasses by a novel Aspergillus niger strain: Effects of $\mathrm{pH}$, sugar and ingredients. Journal of Food: Microbiology, Safety \& Hygene 2: 1-5.

15. Gunes, M. \& Cekic, C. 2004. Some chemical and physical properties of fruits of different mulberry species commonly grown in Anatolia, Turkey. Asian Journal of Chemistry, 16(3): 1849-1855.

16. Faruk, M.O., Mumtaz, T., Rashid, H.O., Zhang, Y., Liu, S. \& $\mathrm{Wu}, \mathrm{H}$. 2014. Supplementary effect of potato peel hydrolysate on the citric acid production by Aspergillus niger CA16. Biotechnology, 9(8): 308-310.

17. Hang, Y.D., Splittstoesser, D.F., Woodams, E.E. \& Sherman, R.M. 1977. Citric acid fermentation of brewery waste. Journal of Food Science, 42: 383-384.

18. Hu, W., Liu, J., Chen, J.H., Wang, S.Y., Lu, D., Wu, Q.H. $\&$ Li, W.J. 2014. A mutation of Aspergillus niger for hyperproduction of citric acid from corn meal hydrolysate in a bioreactor. Journal of Zhejiang University Science $B, 15(11)$ : 1006-1010.

19. Ikram-ul, H., Ali, S., Qadeer, M.A. \& Iqbal, J. 2004. Citric acid production by selected mutants of Aspergillus niger from cane molasses. Bioresource Technology, 93(2): 125130.

20. Jernejc, K., Cimerman, A. \& Perdih, A. 1982. Citric acid production in chemically defined media by Aspergillus niger. European Journal of Applied Microbiology and Biotechnology, 14(1): 29-33.

21. Kareem, S.O., Akpan, I. \& Alebiowu, O.O. 2010. Production of citric acid by Aspergillus niger using pineapple waste. Malaysian Journal of Microbiology, 6(2): 161-165.

22. Max, B., Salgado, J.M., Rodríguez, N., Cortés, S., Converti, A. \& Domínguez, J.M. 2010. Biotechnological production of citric acid. Brazilian Journal of Microbiology, 41(4): 862-875.

23. Marier, J.R. \& Boulet, M. 1958. Direct determination of citric acid in milk with improved pyridine acetic anhydride method. Journal of Dairy Science, 41: 16831692.
24. Muna, B.A. \& Haider, M.M. 2018. Effect of some physiological factors on citric acid production by three isolates of Aspergillus niger acid-hydrolyzed sawdust as a carbon source. Revista Innovaciencia, 6(2): 1-9.

25. Rehman, S., Aslam, H., Ahmad, A., Khan, S.A. \& Sohail, M. 2014. Production of plant cell wall degrading enzymes by monoculture and co-culture of Aspergillus niger and Aspergillus terreus under SSF of banana peels. Brazilian Journal of Microbiology, 45(4): 1485-1492.

26. Show, P.L., Oladele, K.O., Siew, Q.Y., Aziz Zakry, F.A., Lan, J.C.W., \& Ling, T.C. 2015. Overview of citric acid production from Aspergillus niger. Frontiers in Life Science, 8(3): 271-283.

27. Soccol, C.R., Vandenberghe, L.P.S., Rodrigues, C. \& Pandey, A., 2006. New perspectives for citric acid production and application. Food Technology and Biotechnology, 44: 141-149.

28. Taskin, M., Tasar, G.E. \& Incekara, U. 2013. Citric acid production from Aspergillus niger MT-4 using hydrolysate extract of the insect Locusta migratoria. Toxicology and Industrial Health, 29(5): 426-434.

29. Torrado, A.M., Cortés, S., Salgado, J.M., Max, B., Rodríguez, N., Bibbins, B.P., Converti, A. \& Domínguez, J.M. 2011. Citric acid production from orange peel wastes by solid-state fermentation. Brazilian Journal of Microbiology, 42(1): 394-409.

30. Vandenberghe, L.P., Soccol, C.R., Pandey, A. \& Lebeault, J.M. 1999. Microbial production of citric acid. Brazilian Archives of Biology and Technology, 42(3): 263-276.

31. Velmurugan, P., Hur, H., Balachandar, V., KamalaKannan, S., Lee, K. J., Lee, S. M., Chae, J.C., Shea, P.J. \& Oh, B.T. 2011. Monascus pigment production by solidstate fermentation with corn cob substrate. Journal of Bioscience and Bioengineering 112: 590-594.

32. Watanabe, T., Suzuki, A., Nakagawa, H., Kirimura, K. \& Usami, S. 1998. Citric acid production from cellulose hydrolysate by a 2-deoxyglucose-resistant mutant strain of Aspergillus niger. Bioresource Technology, 66(3): 271-274. 